\title{
PERAN PELATIHAN KETAHANAN DAN MOTIVASI BAGI PENINGKATAN KINERJA GURU HONORER DI KABUPATEN BANDUNG BARAT
}

\author{
Bob Foster ${ }^{1}$, Fitriani Reyta ${ }^{2}$, Susan Purnama ${ }^{3}$, Bernadetha Nadeak ${ }^{4}$, Elferida Sormin ${ }^{5}$ \\ 1, 2, 3 Universitas Informatika dan Bisnis Bandung, Bandung, Indonesia \\ ${ }^{4,5}$ Universitas Kristen Indonesia, Jakarta, Indonesia \\ E-mail: bobriset@unibi.ac.id ${ }^{1}$, fitrianireyta@unibi.ac.id², susanpurnama@unibi.ac.id ${ }^{3}$, \\ bernadetha.nadeak@uki.ac.id ${ }^{4}$, elferida.sormin@uki.ac.id ${ }^{5}$
}

\begin{abstract}
Abstrak
Untuk mencipakan siswa yang berkualitas salah satunya dengan meningkatkan ketahanan seorang guru. Ketahanan guru dalam menghadapi kondisi sulit perlu menjadi perhatian pimpinan sekolah dalam upaya peningkatan kualitas pendidikan, dengan asumsi ketahanan akan meningkatkan kinerja guru dan menentukan pencapaian tujuan pendidikan. Selain ketahanan guru motivasi dari pihak sekolah juga memiliki peranan penting. Jika motivasi sekolah rendah, maka akan berakibat buruk pada kinerja guru. Dengan adanya fenomena tersebut, terdapat kemungkinan penurunan kinerja guru honorer. Keberhasilan sekolah dalam memperbaiki kinerja guru dapat dipengaruhi pada pemberian pelatihan bagi peningkatan kualitas sumber daya guru dalam bekerja salah satunya pelatihan bagi ketahanan guru dalam mengatasi rintangan mengajar dan menhadapi kondisi sulit. Penelitian kuantitatif ini adalah hasil pengembangan pengabdian kepada masyarakat yang dilakukan oleh akademisi dari fakultas ekonomi dan bisnis Universitas Informatika dan Bisnis Bandung, dengan tujuan menguji pengaruh pelatihan ketahanan guru dan pemberian motivasi terhadap peningkatan kinerja pada 100 (seratus) guru honorer di Kabupaten Bandung Barat. Hipotesis diuji dengan analisis data Partial Least Square (PLS). Hasil menunjukkan bahwa pelatihan ketahanan diri meningkatkan kinerja guru sedangkan motivasi tidak beperan meningkatkan kinerja guru honorer di Kabupaten Bandung Barat.
\end{abstract}

Kata Kunci: Guru, Honorer, Ketahanan Diri, Motivasi, Kinerja.

\begin{abstract}
To create quality students, one of them is by increasing teacher resilience. The resilience of teachers in facing difficult conditions needs to be the concern of school leaders in efforts to improve the quality of education, with the assumption that resilience will improve teacher performance and determine the achievement of educational goals. Apart from the resilience of teachers, motivation from the school also has an important role. If school motivation is low, it will have a negative impact on teacher performance. With this phenomenon, there is a possibility of a decline in the performance of honorary teachers. The success of schools in improving teacher performance can be influenced by providing training to improve the quality of teacher resources at work, one of which is training for teacher resilience in overcoming teaching obstacles and dealing with difficult conditions. This quantitative research is the result of community service development carried out by academics from the faculty of economics and business, University of Informatics and Business Bandung, with the aim of examining the effect of teacher resilience training and motivation on improving performance in 100 (one hundred) honorary teachers in West Bandung Regency. The hypothesis was tested by using Partial Least Square (PLS) data analysis. The results show that self- resistance training improves teacher performance while
\end{abstract}


motivation does not play a role in improving the performance of honorary teachers in West Bandung Regency

\section{Keywords: Teacher, Honorary, Self-Resilience, Motivation, Performance.}

\section{PENDAHULUAN}

Kondisi sulit dan penghasilan yang rendah pada guru honorer merupakan masalah pokok yang perlu diperhatikan oleh sekolah dalam upaya peningkatan kualitas pendidikan saat ini, dibutuhkan komitmen sekolah terhadap pemenuhan hak guru honorer. Jika komitmen sekolah rendah, maka akan berakibat buruk pada prestasi belajar siswa. Guru dituntut untuk dapat memberikan kinerja terbaik pada sekolah sesuai dengan kompetensi yang dimilikinya. Selain kompetensi, seorang guru juga harus memiliki komitmen akan mencurahkan perhatian secara total. Adanya kompensasi merupakan salah satu alat pembangkit semangat dan motivasi guru untuk dapat tetap berkomitmen dengan pekerjaanya (Qortunnada, 2015). Kompensasi yang diberikan kepada guru seharusnya cukup untuk dapat memenuhi kebutuhan hidupnya. Fakta di Indonesia, khususnya Kabupaten Bandung Barat hanya guru yang bergelar PNS yang memiliki kompensasi yang cukup, untuk guru honorer, dibayar berdasarkan kebijakan sekolah tempat dimana ia mengajar sesuai dengan jam pelajaran. Sejak tahun 2019, guru honorer di Bandung Barat menerima upah Rp. 1.500.000,- (Satu Juta Lima Ratus Ribu Rupiah) dari yang semula Rp. 500.000,(Lima Ratus Ribu Rupiah) setiap bulan.
Kenaikan ini diprakarsai oleh Bupati Bandung Barat Aa Umbara Sutisna. Walaupun dengan kenaikan upah tersebut, masih jauh di bawah UMK Kabupaten Bandung Barat yaitu sebesar Rp 2,9 juta (Dua Juta Sembilan Ratus Ribu Rupiah).

Fenomena tersebut, menimbulkan adanya penurunan kinerja guru honorer. Padahal jika kinerja para guru honorer baik, maka akan memberikan kontribusi terhadap sekolah atau institusi masingmasing. Keberhasilan sekolah dalam memperbaiki kinerja guru sangat tergantung pada kualitas sumber daya manusia yang bersangkutan dalam bekerja. Kinerja merupakan hasil kerja yang dapat dicapai oleh seseorang atau sekelompok orang dalam suatu organisasi baik secara kuantitatif maupun kualitatif (Mathis dan Jackson, 2012).

Setiap kegiatan yang dilakukan oleh seseorang didorong oleh suatu kekuasaan dalam diri orang tersebut, kekuatan pendorong inilah yang disebut motivasi. Motivasi kerja karyawan atau dalam penelitian ini adalah motivasi kerja guru honorer dapat dianggap sederhana dan dapat pula menjadi masalah yang kompleks, karena pada dasarnya manusia mudah untuk dimotivasi dengan memberikan apa yang menjadi keinginannya. Ada tiga elemen kunci dalam motivasi yaitu upaya, tujuan 
organisasi dan kebutuhan. Pada umumnya kinerja yang tinggi selalu dihubungkan dengan motivasi kerja yang tinggi pula. Jika dihubungkan dengan keadaan guru honorer saat ini, maka tidak heran bahwa terjadi penurunan kinerja dikarenakan adanya keadaan ekonomi sulit yang dihadapi oleh para guru honorer. Untuk mendorong peningkatan kinerja para guru honorer, dibutuhkan keyakinan diri akan kemampuan untuk menghadapi kendala mengajar, sikap ketahanan diri menghadapi kesulitan ini dinamakan adversity quotient (Stoltz, 2000)

Adversity quotient merupakan bentuk kecerdasan yang melatar belakangi kesuksesan seseorang dalam menghadapi tantangan disaat terjadi kesulitan. Jika seseorang memiliki kualitas adversity quotient yang baik maka dianggap akan mampu mengatasi rintangan yang menghalangi seseorang dalam mencapai tujuannya. Tanpa adanya adversity quotient yang baik maka dikhawatirkan para guru honorer akan mengalami frustasi dan kegamangan dalam menjalani pekerjaannya sehari-hari. Objek dari penelitian ini adalah para guru honorer di Kabupaten Bandung Barat. Berdasarkan latar belakang diatas, maka penelitian ini dimaksudkan untuk mengetahui bagaimana "Peranan Adversity Quotient Terhadap Peningkatan Kinerja Guru Honorer di Kabupaten Bandung Barat dimediasi oleh Motivasi".
Ketahanan Diri Guru dan Kinerja dalam Mengajar.

Adversity quotient dikembangkan oleh Paul G. Stoltz, Ph.D, seorang. seorang konsultan pendidikan berbasis skill (Stoltz, 2000). Dilatarbelakangi konsep kecerdasan (IQ dan EQ) yang telah ada saat ini dianggap belum cukup untuk menjadi modal seseorang menuju kesuksesan, oleh karena itu Stoltz kemudian mengembangkan sebuah konsep mengenai kecerdasan adversity. Adversity dalam kamus bahasa Inggris berarti kesengsaraan dan kemalangan, sedangkan quotient diartikan sebagai kemampuan atau kecerdasan. Sedangkan menurut Stoltz (2000) adversity quotient merupakan kemampuan yang dimiliki seseorang dalam mengamati kesulitan dan mengolah kesulitan tersebut dengan kecerdasan yang dimiliki sehingga menjadi sebuah tantangan untuk diselesaikan. Adversity quotient sebagai suatu kemampuan terdiri dari empat dimensi yang disingkat dengan sebutan CO2RE yaitu dimensi control, origin- ownership, reach, dan endurance (Stoltz, 2000). Kinerja guru adalah hasil kerja secara kualitas dan kuantitas yang dicapai oleh seorang guru dalam melaksanakan tugasnya sesuai dengan tanggung jawab yang diberikan kepada guru tersebut.

Yazon (2019) menyatakan dalam penelitianya pada guru di Filipina bahwasanya ada hubungan anatara 
ketahanan diri seorang guru terhadap penguasan kelas mengajar, namun tingkat tinggi rendahnya ketahanan diri tidak menjamin sepenuhnya peningkatan kinerja, ditemukan juga bahwa ketahanan diri yang tinggi memiliki kinerja sedang namun ketahanan diri rendah kinerjanya baik. Asumsi tersebut tidak mendukung sepenuhnya teori dari ketahanan diri oleh Stolz (2000). Maiquez et all (2015) menyatakan terdapat hubungan yang tidak signifikan pada kecakapan emosional dan ketahanan diri pengajar terhadap prestasi akademik. Meski tidak signifikan, terdapat persentase kecil yang disebabkan oleh faktor lain.

Parvathy, U. dan Praseeda, M. (2014) mengeksplorasi hubungan antara kecerdasan adversity dan permasalahan akademik di antara guru dan siswa, hasilnya menyatakan bahwa seseorang yang memiliki kemampuan untuk mengatasi kesulitan dapat dengan mudah menyelesaikan masalah akademik. Terdapat hubungan negatif antara masalah akademik dengan Ketahanan diri. Semakin tinggi nilai ketahanan diri, semakin rendah masalah yang dimiliki seseorang dalam akademik. Studi ini didukung oleh Bakare (2013) menunjukkan hasil ketahanan diri dalam menghadapi kesulitan memiliki hubungan yang signifikan dengan kinerja akademik. Seiring ketahanan diri meningkat, kinerja akademis pengajar juga meningkat.
Praditsang dan Hanafi (2013) meneliti hubungan antara adversity quotient dan perilaku belajar sementara Cornista dan Macasaet (2013) menyelidiki hubungan antara adversity quotient dan motivasi berprestasi. Kedua studi tersebut meneliti kesulitan peserta dan faktor lainnya, seperti usia dan jenis kelamin, yang dianggap memiliki hubungan yang signifikan dengan kecerdasan adversity terbukti tidak berpengaruh. Pada penelitian Praditsang dan Hanafi (2013) nilai AQ tinggi sedangkan pada penelitian Cornista dan Macasaet memiliki skor $A Q$ mayoritas yang rendah. Penelitian Tansiongco dan Ibarra (2020) menyatakan hasil berbeda, seorang akademisi memiliki tingkat kecerdasan yang tinggi - dalam pengendalian kesulitan kemungkinan besar akan bekerja lebih baik dalam kepemimpinan instruksional dan standar kualitas untuk program pendidikan dasar. Diperlukan pelatihan untuk mengasimilasi kecerdasan menghadapi kesulitan dan peningkatan kualifikasi akademisi untuk meningkatkan kinerja organisasi dalam sistem manajemen pendidikan.

Berdasarkan beberapa hasil penelitian terdahulu diatas menghasilkan hipotesis pertama $\left(\mathrm{H}_{1}\right)$ bahwa : Ketahanan diri menghadapi kesulitan berpengaruh terhadap peningkatan kinerja akademisi. 


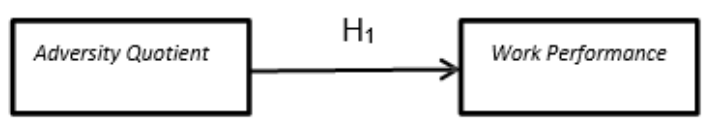

Gambar 1. Hipotesis Penelitian Kesatu

H1: Ketahanan diri guru honorer berpengaruh terhadap Kinerja Mengajar.

Motivasi dan Peningkatan Pengaruh Ketahanan Diri Guru pada Kinerja Mengajar

Dari perspektif pencapaian ketahanan diri dan motivasi diri, akademisi secara luas dicirikan dengan motif mereka untuk menghindari kegagalan dan mendekati kesuksesan (Atkinson 1957; Covington, 1992; Covington \& Omelich, 1991; McClelland, 1965). Berbasis pada model motivasi berprestasi kebutuhan, siswa dapat dikarakterisasikan dalam tiga tipologi: akademisi yang berorientasi pada keberhasilan, akademisi yang menghindari kegagalan, dan akademisi yang menerima kegagalan. Akademisi yang berorientasi pada kesuksesan cenderung optimis, bersikap proaktif dan positif terhadap orientasi mereka, dan tidak dilemahkan oleh kegagalan melainkan meresponsnya dengan optimisme dan energi (Covington \& Omelich, 1991; Martin, 1998, 2001, in press; Martin et al., 2001). Para akademisi ini, dapat dikatakan, sangat termotivasi dalam hal yang positif dan proaktif dalam merespons secara adaptif terhadap kemunduran jika itu harus terjadi (Martin et al., 2001)

Motivasi dapat dikonseptualisasikan sebagai energi dan dorongan akademisi saat proses belajar- mengajar, bekerja efektif, dan mencapai potensi mereka di sekolah dan perilaku yang mengikutinya. Motivasi berperan besar dalam minat dan kegemaran akademisi di sekolah. Motivasi juga mendukung pencapaian mereka (Martin, 2001, in press; Martin, Marsh, \& Debus, 2001a, 2001b, dicetak; Meece, Wigfield, \& Eccles, 1990; Schunk, 1990). Bagaimanapun, energi dan dorongan untuk belajar, bekerja secara efektif, dan berprestasi untuk potensi seseorang tidak cukup untuk menghadapi kegagalan akademis atau studi yang berlebihan menyebabkan tekanan dan stres. Tanpa tingkat ketahanan tertentu terhadap jenis tantangan ini, kondisi akademisi yang termotivasi mungkin akan berkurang. Masalah ketahanan ini muncul dengan pertimbangan beberapa fenomena antara lain, mengapa motivasi beberapa akademisi menjadi lemah oleh kegagalan mengakibatkan, kinerja buruk, stres, dan tekanan mengajar sementara yang lain bangkit, pulih, dan melanjutkan hidup? Mengapa beberapa akademisi terjebak dalam kondisi underachievement sementara yang lain secara proaktif menanggapi kinerja yang buruk dan memecahkan kondisi tersebut? Mengapa beberapa akademisi mengalami burn out di bawah tekanan sekolah sementara yang 
lain bersemangat dan menerima tantangan di hadapan mereka?.

Howard \& Johnson (2000) mengutarakan bahwa untuk menjawab perbedaan kondisi tersebut adalah berasal dari ketahanan diri masingmasing akademisi, dimana ketahanan diri didefinisikan sebagai proses, kapasitas, atau hasil adaptasi yang berhasil pada keadaan yang menantang atau mengancam pada diri seseorang. Sekolah adalah tempat penting di mana ketahanan diri akademisi dapat ditingkatkan (Cunningham, Brandon, \& Frydenberg, 1999; Frydenberg, 1999; Fuller, 2001; Fuller, McGraw, \& Goodyear, 1999; Howard \& Johnson, 2000; Longaretti, 2001; Parker \& Hendy, 2001; Speirs \& Martin, 1999). Berdasarkan beberapa penelitian terdahulu maka dapat diasumsikan bahwa :

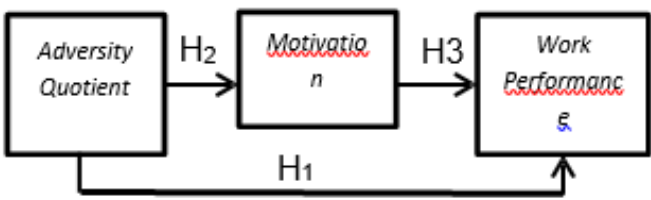

Gambar. 1. 2 Hipotesis Penelitian Kedua dan Ketiga

Berdasarkan gambar 1.2. diatas dapat diasumsikan ;

H1: Ketahanan diri berperan dalam meningkatkan kinerja guru honorer secara langsung

H2: Motivasi berperan meningkatkan pengaruh ketahanan diri pada kinerja guru honorer

\footnotetext{
H3: Motivasi berpengaruh pada kinerja guru honorer.
}

METODE

Pengujian pemberian pelatihan terhadap ketahanan diri dan pengaruhnya pada peningkatan kinerja dimediasi oleh motivasi yang dilakukan pada bulan Agustus 2020 menggunakan pendekatan kuantitatif, sebanyak 100 guru honorer di Kabupaten Bandung Barat diambil sebagai sampel dengan metode non-probability sampling, tehnik yang sesuai untuk penelitian ini adalah quota sampling. Pengambilan sampel kuota dapat digambarkan sebagai proses penilaian dua langkah. Tahap pertama melibatkan pengembangan kategori kontrol, atau kuota, dari elemen populasi. Pada tahap kedua judgemental atau convenience sampling kemudian digunakan untuk pemilihan elemen sampel (Malhotra, 2007). Responden sebagai sampel dalam penelitian ini adalah Guru Honorer yang ada di Kota Bandung Barat.

Selanjutnya jumlah kuesioner yang akan dibagikan kepada 100 responden pada daftar sekolah yang mewakili populasi adalah: 1) SMAN Padalarang, 2) SMAN 1 Cisarua Lembang, 3) SMAN 1 Batu Jajar, 4) SMAN 1 Parongpong, 5) SMK Bandung Barat 2. Setiap sekolah akan diwakili oleh 20 responden atau tenaga pengajar, maka nilai 5 sekolah akan menjadi 5 × $20=100$ responden di Kota Bandung Barat. Untuk analisis data, validitas, reliabilitas, dan pengujian hipotesis yang digunakan dalam penelitian ini adalah partial least 
square yang didukung oleh software $\mathrm{XL}$ Stat untuk pengolahan datanya. Partial Least Square (PLS) merupakan bagian dari Structural Equation Modeling (SEM). Metode PLS ini merupakan metode baru yang banyak digunakan dalam penelitian karena dapat menggunakan jumlah sampel yang lebih sedikit (Abdillah \& Hartono, 2015).

\section{HASIL DAN PEMBAHASAN}

Hasil kuisioner yang diberikan kepada 100 (serratus) sampel gutu honorer di Bandung Barat kemudian diolah menggunakan software Excell dan di jalankan melalui XL STAT untuk memperoleh hasil validitas, reabilitas dan pengujian hipotesis, hasil validitas pada tabel 1 mengindikasikan bahwa seluruh dimensi yang mewakili variabel dinyatakan valid dan dapat digunakan dalam penelitian ini.

Tabel 1. Cross-loadings validitas item yang diukur (variabel manifes monofaktor / 1)

\begin{tabular}{|l|r|r|r|}
\hline & $\begin{array}{c}\text { Adversity } \\
\text { Quotient }\end{array}$ & Motivation & $\begin{array}{c}\text { Work } \\
\text { Performance }\end{array}$ \\
\hline Control & $\mathbf{0 . 9 5 8 4}$ & 0.6438 & 0.8008 \\
Origin Owneship & $\mathbf{0 . 9 1 6 8}$ & 0.6553 & 0.8042 \\
Reach & $\mathbf{0 . 8 5 7 7}$ & 0.4086 & 0.6147 \\
Endurance & $\mathbf{0 . 8 5 5 0}$ & 0.6722 & 0.7148 \\
Need for Power & 0.5531 & $\mathbf{0 . 8 5 1 2}$ & 0.7352 \\
Need for & 0.6416 & $\mathbf{0 . 9 5 0 6}$ & 0.8666 \\
Achievement & & & \\
Need for Affiliation & 0.6527 & $\mathbf{0 . 9 3 4 6}$ & 0.8452 \\
\hline Quality & 0.6912 & 0.9043 & $\mathbf{0 . 9 0 7 4}$ \\
Quantity & 0.5844 & 0.5008 & $\mathbf{0 . 6 7 7 4}$ \\
Responsibility & 0.7796 & 0.5493 & $\mathbf{0 . 7 9 0 8}$ \\
\hline Initiative & 0.6406 & 0.8865 & $\mathbf{0 . 8 5 8 0}$ \\
\hline
\end{tabular}

\section{Sumber : data kuisioner diolah dengan XL STAT, Agustus 2020}

Dari tabel 1 diatas, hasil pengolahan data dari kuisioner menggunakan software XLSTAT menunjukkan indikator nilai validitas konvergen masing-masing variabel mempunyai factor loading lebih dari 0.50 artinya pernyataan dalam kuisioner valid dan dapat mewakili variabel ketahanan diri, motivasi dan kinerja dalam penelitian ini, semakin tinggi faktor loading maka semakin tinggi validitasnya.

Tabel 2. Pengukuran Reliabilitas

\begin{tabular}{|l|r|r|r|}
\hline \multicolumn{1}{|c|}{$\begin{array}{c}\text { Latent } \\
\text { variable }\end{array}$} & $\begin{array}{c}\text { Dimensi } \\
\text { ons. }\end{array}$ & $\begin{array}{c}\text { Cronbach's } \\
\text { alpha }\end{array}$ & $\begin{array}{c}\text { D.G. rho } \\
\text { (PCA) }\end{array}$ \\
\hline $\begin{array}{l}\text { Adversity } \\
\text { Quotient }\end{array}$ & 4 & 0.9197 & 0.9437 \\
\hline Motivation & 3 & 0.8995 & 0.9377 \\
\hline $\begin{array}{l}\text { Work } \\
\text { Performance }\end{array}$ & 4 & 0.8257 & 0.8856 \\
\hline
\end{tabular}

Sumber : data kuisioner diolah dengan XL STAT, Agustus 2020.

Dari tabel 2. di atas, hasil pengolahan data dari kuesioner dengan menggunakan software XLSTAT menunjukkan bahwa konstruk masingmasing variabel memiliki Cronbach Alpha lebih dari 0,70 artinya pernyataan dalam kuesioner reliabel dan dapat mewakili variabel ketahanan diri, motivasi dan kinerja dalam penelitian ini. Gambar 1.3 dibawah ini menggambakan hasil pengujian ketiga hipotesis:

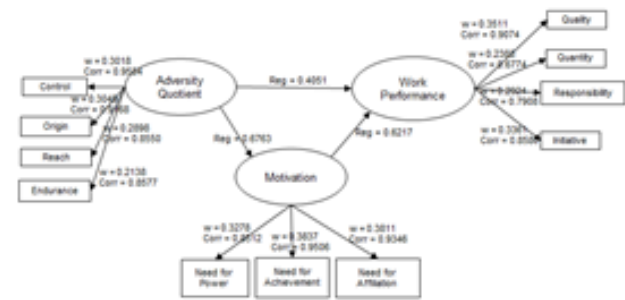

Gambar 1.3 Hasil Uji hipotesis menggunakan metode PLS dijalankan melalui software XL STAT

(Sumber - data kuisioner diolab dengan XL STAT, Agustus 2020) 
Table 4. Path coefficients

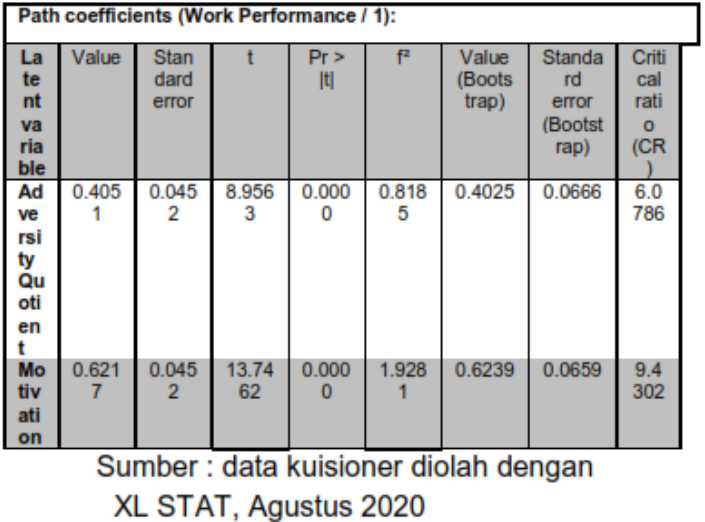

Ketahanan diri dan motivasi secara simultan berpengaruh terhadap Adversity Quotient, jika F hitung > dari F tabel, (maka model signifikan, untuk $\mathrm{n}=$ 100 dan $\mathrm{k}=2 \mathrm{t}$ tabel 3,09 dan $\mathrm{F}$ hitung 401,4450 berarti Ha2 diterima Model signifikan Adversity Quotient dan Motivation berpengaruh secara simultan terhadap kinerja sebesar $80 \%$. dari pengujian dapat disimpulkan:

1) H3 diterima, Motivasi berpengaruh terhadap Kinerja guru honorer

2) $\mathrm{H} 1$ diterima. Adversity Quotient berpengaruh terhadap kinerja secara langsung.

3) $\mathrm{H} 2$ diterima. Motivasi berperan meningkatkan pengaruh Adversity Quotient terhadap kinerja

4) Persamaan model: Kinerja Guru Honorer $=0.40507$ * Adversity Quotient + $0.62171 *$ Motivasi

Berdasarkan hasil analisis data dalam penelitian ini tidak dapat menunjukkan bahwa adversity quotient berpengaruh secara langsung signifikan terhadap kinerja, motivasi berperan sebagai mediasi yang meningkatkan pengaruh ketahanan diri terhadap kinerja. Hasil penelitian ini mendukung penelitian Martin, 2001, in press; Martin, Marsh, \& Debus, 2001a, 2001b, dicetak; Meece, Wigfield, \& Eccles, 1990; Schunk, 1990) bahwasanya motivasi berpengaruh terhadap kinerja akademisi dan diadalamnya membutuhkan peranan ketahanan diri. Pernyataan dari Howard \& Johnson (2000) yang mengutarakan bahwa untuk menjawab perbedaan kondisi tersebut adalah berasal dari ketahanan diri masing-masing akademisi didukung oleh hasil penelitian ini, semakin tinggi ketahanan diri guru honorer maka semakin tinggi juga peluang peningkatan kinerja guru. Praditsang dan Hanafi (2013) juga Martin et al (2001) menyatakan bahwa ketahanan diri yang tinggi akan diperlihatkan dalam individu ketika mengalami kegagalan dan stress kerja tinggi, hal ini sesuai dengan hasil peneitian ini bahwasanya guru honorer akan diuji ketika tingkat stress kerja mereka tinggi

\section{SIMPULAN}

Saran yang dapat direkomendasikan untuk menunjukkan tingkat adversity quotient yang baik perlu dipertimbangkan dalam mengembangkan potensi guru sebagai sumber daya manusia pengajar, melalui pelatihan dan pengembangan wawasan pengetahuan. Pemerintah dapat mengevaluasi gaji guru yang diberikan sesuai dengan kinerja pekerjaan yang 
ditunjukkan dan pemberian reward seperti bonus tambahan atas pekerjaan yang dilakukan dan kejelasan jalur karir dari honorer menjadi PNS. Sehingga para guru lebih fokus dalam menjalankan karirnya sebagai guru dan memberikan kinerja terbaik dalam profesinya dalam menghasilkan generasi penerus bangsa yang terbaik. Pelatihan untuk memupuk ketahanan diri pada akademisi memiliki peranan penting sesuai dengan hasil penelitian bahwasanya kinerja guru honorer akan meningkat juga. Pemberian motivasi berupa reward dan nominal juga sangat dibutuhkan oleh para akademisi, oleh karena itu pihak sekolah perlu menngkatkan pemberian reward maupun insentif kepada guru honorer.

\section{REFERENSI}

Glinow, Von \& McShane. (2008). Organizational Behavior. New York: McGraw Hill.

Hasibuan, Malayu S. P. (2013).

Manajemen Sumber Daya Manusia, Edisi Revisi. Jakarta: PT Bumi Aksara.

Lipu, Andi Tonra, Syamsu Alam dan Fauziah Umar. (2013). Kepuasan Kerja, Dukungan Organisasi, Gaya Kepemimpinan, Motivasi Kerja terhadap Kinerja Karyawan Pada PT. Bank Mega. Jurnal Program Magister Manajemen Fakultas Ekonomi Universitas Hasanuddin
Lubis, Anggia S. (2018). Pengaruh Adversity Quotient Terhadap Kinerja Karyawan Melalui Motivasi Kerja Sebagai Variabel Intervening (Studi Pada Pengemudi Taksi Konvensional di Kota Medan). Jurnal Konsep Bisnis dan Manajemen Vol. 4.

Mangkunegara, A. A. (2012). Anwar prabu. Manajemen Sumber Daya Manusia Perusahaan.

Fardina, E. (2019). Manajemen pengembangan SDM dalam peningkatan mutu dan daya saing sekolah: studi kasus di SDIT AlHilmi Dompu Tahun Pelajaran 2018/2019 (Doctoral dissertation, UIN Mataram).

Aryasuta, I. W. E., Suparta, I. N., \& Suweken, G. (2014). Pengaruh model pembelajaran berbasis masalah dengan media pembelajaran berbantuan geogebra terhadap prestasi belajar matematika siswa ditinjau dari tingkat ketangguhan siswa. Jurnal Pendidikan dan Pembelajaran Matematika Indonesia, 3(1).

Triastuti, D. A. (2019). Pengaruh lingkungan kerja, kompetensi dan iklim organisasi terhadap kinerja pegawai. Journal of Management Review, 2(2), 203-208. 